\title{
Esophageal papillomatosis complicated by squamous cell carcinoma
}

A 64-year-old woman was referred for investigation of a thickened esophagus on computed tomography (CT) scanning. She had no upper gastrointestinal symptoms, in particular, any dysphagia or weight loss. Nine years previously she had undergone a bone marrow transplant for myelodysplasia for which she was taking $5 \mathrm{mg}$ prednisolone. Endoscopy with a GIF-Q180 gastroscope (Olympus, Tokyo, Japan) demonstrated a circumferential area of multiple confluent papules extending for $5 \mathrm{~cm}$ in the mid-esophagus, with a 2-cm nodule at its distal border. The remainder of the esophagus was normal ( Fig. 1, Video 1). Histological examination revealed atypical squamous epithelial proliferation, consistent with papillomatosis, and evidence of invasive squamous cell carcinoma in the nodule ( Fig.2, Video 1). Studies to identify human papillomavirus (HPV) as potential etiology were not performed. The patient has been referred for chemoradiotherapy. Esophageal papillomatosis is a rare endoscopic finding with an unclear etiology. It has been associated with both HPV and reflux disease [1]. The etiology in our patient may be related to HPV infection secondary to long-term immunosuppression. The typical endoscopic appearance is a single, round, sessile lesion. However, our case, similar to other reports, demonstrates that it might present with multiple lesions [2,3]. Early reports suggested that this was a benign condition and endoscopic surveillance was unnecessary [4]. However as our case demonstrates, confirming other reports, esophageal papillomatosis should be considered a premalignant condition with the potential for squamous cell carcinoma development $[2,3]$. Interestingly, the reported cases of carcinoma have involved extensive rather than isolated lesions.

Small isolated lesions have been successfully treated with endoscopic resection [5]. Due the paucity of reported cases, the best clinical management of extensive papillomatosis remains unclear. If no specific treatment is undertaken, surveillance

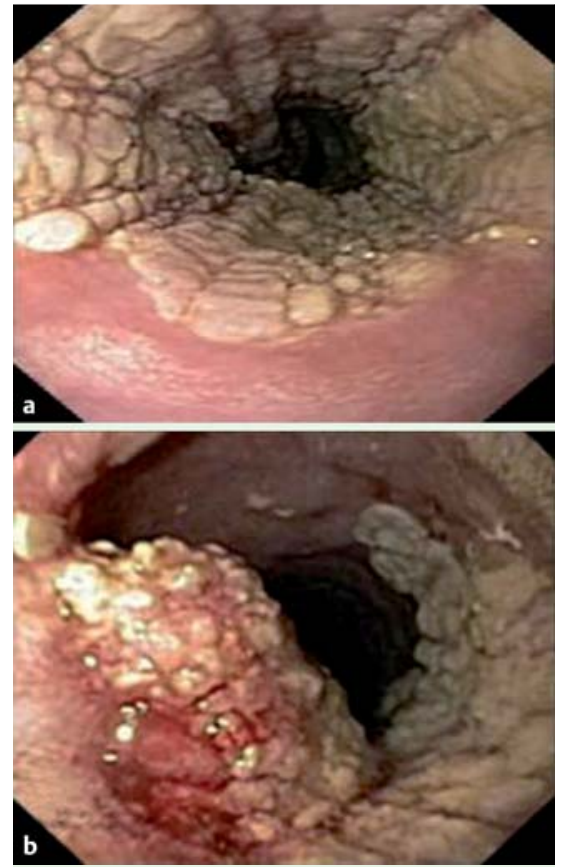

Fig. 1 Endoscopic images of the esophagus in a 64-year-old woman referred for a thickened esophagus on computed tomography (CT) scan. a Multiple confluent papules with circumferential involvement of mid-esophagus. b A discrete nodule at the distal border.

endoscopy should be considered, given the potential for malignant development. The exact surveillance strategy, however, is not known.

Endoscopy_UCTN_Code_CCL_1AB_2AC_3AB

Competing interests: None

\section{Video 1}

Gastroscopy demonstrated a mid-esophageal circumferential area of multiple confluent papules and a 2-cm nodule at the distal border of the confluent area. Histological examination revealed atypical squamous epithelial proliferation consistent with papillomatosis and invasive squamous cell carcinoma in the nodule.

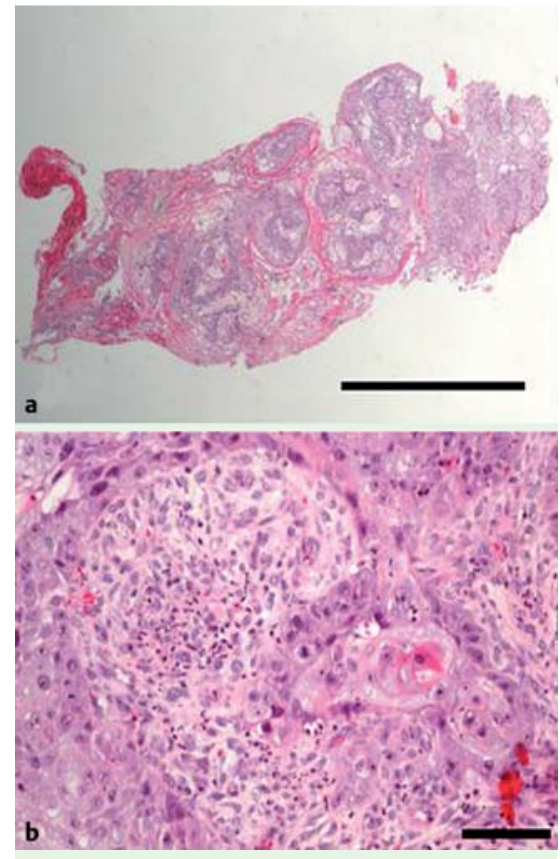

Fig. 2 a Histological section from a biopsy specimen from one of the papules demonstrating atypical squamous epithelial proliferation consistent with papillomatosis. b Histological section from the distal nodule demonstrating invasive squamous cell carcinoma.

\section{F. Donnellan', B. Walker ${ }^{2}$, R. Enns ${ }^{1}$}

${ }^{1}$ Department of Gastroenterology, St. Paul's Hospital, Vancouver, Canada

2 Department of Pathology,

St. Paul's Hospital, Vancouver, Canada 


\section{References}

1 Odze $R$, Antonioli $D$, Shocket $D$ et al. Esophageal squamous papillomas. A clinicopathologic study of 38 lesions and analysis for human papillomavirus by the polymerase chain reaction. Am J Surg Pathol 1993; 17: $803-812$

2 Kao PC, Vecchio JA, Schned LM et al. Esophageal squamous papillomatosis. Eur J Gastroenterol Hepatol 2005; 17: 1233-1237
3 Attila T, Fu A, Gopinath $N$ et al. Esophageal papillomatosis complicated by squamous cell carcinoma. Can J Gastroenterol 2009; 23: 415-419

4 Mosca S, Manes G, Monaco R et al. Squamous papilloma of the esophagus: long-term follow up. J Gastroenterol Hepatol 2001; 16: 857-861

5 Abeid M, Labib S, Neizamy E. Esophageal squamous papilloma. Gastrointest Endosc 2011; 73: 1035

\section{Bibliography}

Dol http://dx.doi.org/

10.1055/s-0031-1291599

Endoscopy 2012; 44: E110-E111

(C) Georg Thieme Verlag KG

Stuttgart · New York

ISSN 0013-726X

\section{Corresponding author}

\section{F. Donnellan}

Department of Gastroenterology St. Paul's Hospital

Vancouver

Canada

fdonnellan77@hotmail.com 